\title{
What the presence of regulated chemical elements in beached lacustrine plastics can tell us: the case of Swiss lakes
}

\author{
Montserrat Filella (D). \\ Juan-Carlos Rodríguez-Murillo (1) • \\ Andrew Turner (1)
}

Received: 27 March 2021 / Accepted: 10 August 2021 / Published online: 6 October 2021

(C) The Author(s) 2021

\begin{abstract}
Plastics $(n=3880)$ have been sampled from 39 beaches of ten Swiss lakes of varying sizes, hydrodynamics, and catchments, with a selection $(n=598)$ analysed for potentially hazardous (and regulated) chemical elements ( $\mathrm{As}, \mathrm{Ba}, \mathrm{Br}, \mathrm{Cd}, \mathrm{Cr}, \mathrm{Hg}$, $\mathrm{Pb}, \mathrm{Sb}, \mathrm{Se}$ ) by X-ray fluorescence spectrometry. Plastic objects and fragments with identifiable or unidentifiable origins were present on all beaches surveyed, and were often most abundant in proximity to major riverine inputs. Chemical elements were detected in between two $(\mathrm{Hg})$ and $340(\mathrm{Ba})$ samples with maximum concentrations exceeding $2 \%$ by weight for $\mathrm{Ba}, \mathrm{Cd}, \mathrm{Cr}, \mathrm{Pb}$, and $\mathrm{Sb}$. Inter-element relationships and characteristics of the samples suggest that elements are largely present as various additives, including pigments (e.g., $\mathrm{Cd}_{2} \mathrm{SSe}, \mathrm{PbCrO}_{4}$ ), stabilizers (in
\end{abstract}

Supplementary information The online version contains supplementary material available at https://doi. org/10.1007/s10661-021-09384-5.

\section{Filella $(\bowtie)$}

Department F.-A. Forel, University of Geneva Boulevard

Carl-Vogt 66, CH-1205 Geneva, Switzerland

e-mail: montserrat.filella@unige.ch

J.-C. Rodríguez-Murillo

Museo Nacional de Ciencias Naturales, CSIC, Serrano 115

dpdo, 28006 Madrid, Spain

A. Turner

School of Geography, Earth and Environmental

Sciences, University of Plymouth, Drake Circus,

PL4 8AA Plymouth, UK polyvinyl chloride), and flame retardants (Br). Observations are similar to, and complement, those previously reported in Switzerland's largest lake (Lake Geneva). Comparison of concentrations of targeted chemical elements in beached plastic with currently used plastics illustrate the interest of these types of measurements in providing an insight into the persistence of plastics in standing stocks and in lakes. This information could help to introduce management schemes that consider whether plastic pollution is new or old and act accordingly.

Keywords Lakes - Plastics - Additives - Antimony · Barium · Bromine $\cdot$ Cadmium $\cdot$ Chromium $\cdot$ Lead · Mercury

\section{Introduction}

Due to their durability and persistence in aquatic environments, plastics have accumulated steadily since first being observed in the 1970s (Carpenter \& Smith, 1972; Colton et al., 1974) and have been a ubiquitous contaminant of the whole planet for many years (France, 1992). The impact of plastics in the environment has been the object of enormous scientific study, with more than 3000 papers being published since 1972 according to a Web of Science search conducted in December 2020. However, different environmental compartments and aspects of the problem have received differing degrees of attention. 
Fig. 1 Location of the 39 beaches sampled in the ten Swiss lakes. See Table 2 for the correspondence of numbers. In red, beaches sampled in Lake Geneva in Filella and Turner (2018)

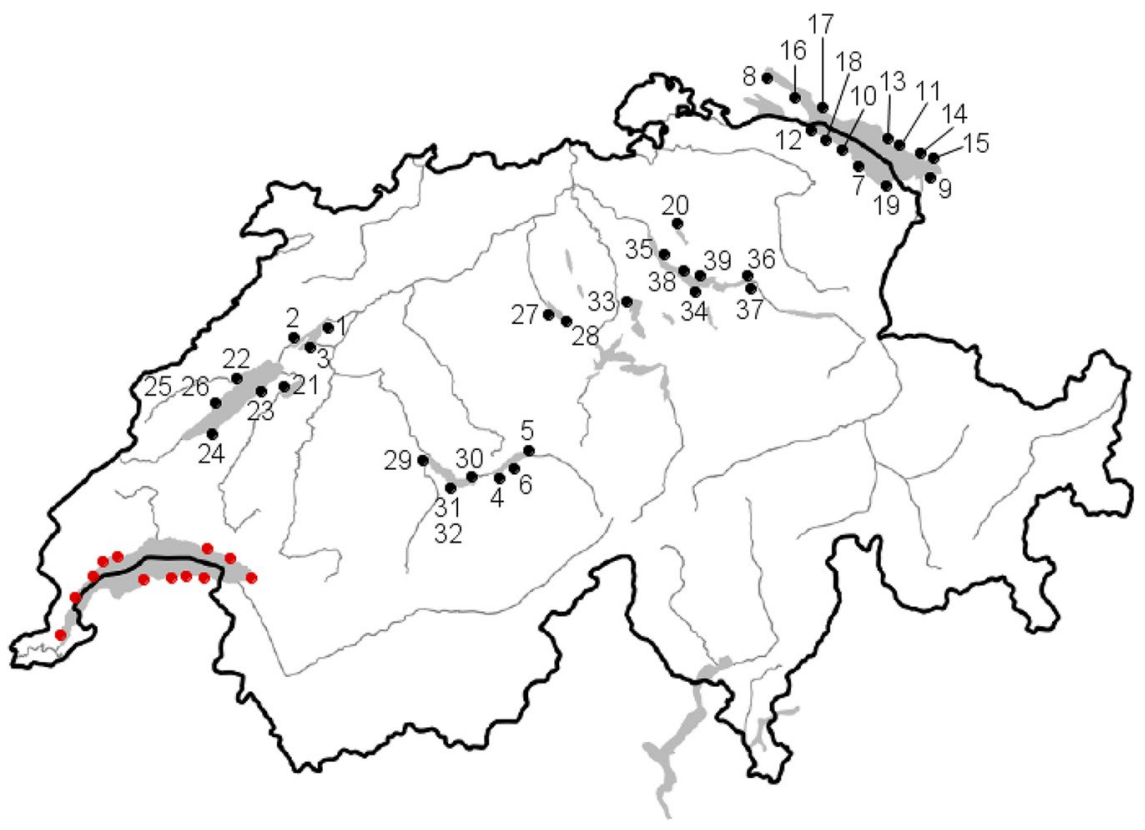

Thus, with respect to size, more attention has been paid to so-called microplastics than mesoplastics and macroplastics. However, the latter are also of concern because (1) they are a nuisance with effects in tourism and public perception (Beaumont et al., 2019; Krelling et al., 2017), (ii) they are an important source of microplastics through degradation and fragmentation (Barnes et al., 2009; Karlsson et al., 2018; Lambert \& Wagner, 2016), and (iii), they have been shown to directly affect biota health through ingestion, entanglement, etc. (Collard et al., 2018; Scherer et al., 2017). Regarding aquatic compartments, there is much less information on plastics in freshwaters than in marine systems. For instance, a review by Blettler et al. (2018) revealed that between January 1980 and May 2018, 13\% of studies on microplastics were devoted to freshwaters and $87 \%$ to marine waters. With respect to chemical associations, the emphasis of most studies has been on the capacity of plastics, and in particular microplastics, to sorb water-borne organic pollutants and to leach additives such as plasticizers (Hahladakis et al., 2018; Oehlmann et al., 2009). The roles and impacts of chemical elements as potentially hazardous additives have received relatively little scientific consideration with research often centred on trace element adsorption (Turner \& Filella, 2021a, 2021b, 2021c).

The present study combines the three aspects described above: freshwaters, potentially hazardous chemical elements, and macroplastics and mesoplastics, by performing X-ray fluorescence (XRF) analysis of beached plastic samples collected from a variety of Swiss lakes. The study continues and complements a previous survey performed in Lake Geneva (Switzerland/France) in 2018 where the presence of potentially hazardous elements was determined in plastic items stranded on 12 beaches (Filella \& Turner, 2018) and aims to check if observations in this lake are different to or representative of other lakes of varying physical and catchment characteristics. An additional aim is to evaluate whether the determination of metal contents in plastics might provide information on the age of plastics and their potential accumulation in lakes. Whether surveys of litter stranded on beaches provide a reliable indicator of the abundance of plastic waste in waters is an open question (Ryan et al., 2014, and references therein), but much of what we know about ocean litter is based on surveys of litter stranded on beaches and this is also the case for lakes. 
Table 1 Lakes studied and their physical characteristics ${ }^{\mathrm{a}}$

\begin{tabular}{|c|c|c|c|c|c|c|c|c|}
\hline & Lake & Altitude/m & $\begin{array}{l}\text { Catchment } \\
\text { area }^{\mathrm{b}} / \mathrm{km}^{2}\end{array}$ & $\begin{array}{l}\text { Maximum } \\
\text { depth/m }\end{array}$ & Surface area $/ \mathrm{km}^{2}$ & Volume $/ \mathrm{km}^{3}$ & $\begin{array}{l}\text { Residence } \\
\text { time/yr }\end{array}$ & $\begin{array}{l}\text { Residents in } \\
\text { catchment } \\
\text { area }^{c}\end{array}$ \\
\hline 1 & Bienne & 429 & 8196 & 74 & 37.8 & 1.12 & 0.16 & 1095.5 \\
\hline 2 & Brienz & 564 & 1108 & 261 & 29.8 & 5.15 & 2.6 & 26.1 \\
\hline 3 & Constance & 395 & 11,461 & 254 & 536 & 48 & 4.1 & 455 \\
\hline 4 & Geneva & 372 & 7419 & 310 & 580.1 & 89 & 11.3 & 906.2 \\
\hline 5 & Greifen & 435 & 156 & 32 & 8.5 & 0.1485 & 1.2 & 108.4 \\
\hline 6 & Morat & 429 & 690 & 45 & 22.7 & 0.531 & 1.5 & 87.8 \\
\hline 7 & Neuchâtel & 429 & 2664 & 153 & 242 & 13.9 & 8.0 & 322.6 \\
\hline 8 & Sempach & 504 & 61 & 87 & 14.4 & 0.639 & 18.5 & 15.8 \\
\hline 9 & Thun & 558 & 2404 & 217 & 47.7 & 6.42 & 1.9 & 108.2 \\
\hline 10 & Zug & 414 & 212 & 198 & 38.4 & 3.2 & 16.7 & 102.2 \\
\hline 11 & $\begin{array}{l}\text { Zurich Untersee } \\
\text { Zurich Obersee }\end{array}$ & $\begin{array}{l}406 \\
406\end{array}$ & $\begin{array}{l}1757 \\
1563\end{array}$ & $\begin{array}{l}136 \\
48\end{array}$ & $\begin{array}{l}65.1 \\
20.7\end{array}$ & $\begin{array}{l}3.4 \\
0.47\end{array}$ & $\begin{array}{l}1.4 \\
0.2\end{array}$ & $\begin{array}{l}434.1 \\
167.7\end{array}$ \\
\hline
\end{tabular}

${ }^{\text {a }}$ Sources: Federal Office for the Environment (www.bafu.admin.ch)

${ }^{\mathrm{b}}$ Excluding lake surface

${ }^{\mathrm{c}}$ In thousands of inhabitants

\section{Materials and methods}

Study sites and sampling

Thirty-nine beaches along the Swiss, German, and Austrian shores of ten Swiss lakes were sampled for the present study. Their locations are shown in Fig. 1, and the main characteristics of the lakes (altitude, catchment area, depth, volume, surface, residence time) are detailed in Table 1. Since lake beaches are used for recreational purposes and some beaches are routinely cleaned, particularly in summer, sampling took place before the Easter holiday break. Most anthropogenic litter observed on each beach was plastic, and all items of this nature retrieved are photographed in the Supporting Information files.

Across the entire beach, any item wholly or largely made of plastic that was visible at the surface to the naked eye was retrieved by hand. Samples from each beach were returned to the laboratory in clear, polyethylene zip-lock bags. They were cleared of any visible extraneous material, counted, photographed, and weighed. Table 2 contains information about the total number of items collected, the number analyzed by XRF, and the average item weight for each beach, along with exact locations of the beaches, their lengths, and dates of sampling. Values of item linear densities (items $\mathrm{m}^{-1}$ ), also shown, allow survey results to be compared regardless of the size of the survey. Standardised protocols for litter surveys of marine beaches, such as OSPAR's(OSPAR, 2010), recommend results to be expressed as items per $100 \mathrm{~m}$ or $1 \mathrm{~km}$, but this guideline is linked to the minimum lengths recommended to be sampled ( $100 \mathrm{~m}$ and, if possible, over $1 \mathrm{~km}$ in length) which, in our opinion, is not applicable to most lake beaches.

\section{$\mathrm{XRF}$ analysis}

Selected samples of plastic (excluding rubbers and foamed materials) of various size, colour, texture, and condition from each location were analyzed by energydispersive XRF spectrometry. Multiple samples of relatively new objects known to be free of potentially hazardous elements were not considered (e.g., cotton buds, new plastic caps, food wrapping). Therefore, the percentage of objects where a given element is detected is not necessarily representative of its presence on all retrieved plastic items. Rather, our choice was driven by the objective of the study: to check whether plastics containing potentially hazardous chemical elements are present in lake beaches.

Details of the XRF analysis are given in Turner and Solman (2016) and are summarized as follows. A battery-powered Niton analyzer (model XL3t 950 
Table 2 Name and location of each beach and information about the number (and average weight) of items retrieved and the number of XRF analyses performed

\begin{tabular}{|c|c|c|c|c|c|c|c|c|c|}
\hline $\begin{array}{l}\text { Beach } \\
\text { ID }\end{array}$ & Lake & Beach $^{a}$ & Location & $\begin{array}{l}\text { Beach } \\
\text { length/m }\end{array}$ & Date & $\begin{array}{l}\text { Number } \\
\text { of items }\end{array}$ & 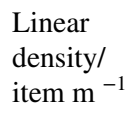 & $\begin{array}{l}\text { Number of } \\
\text { analyses }\end{array}$ & $\begin{array}{l}\text { Mean } \\
\text { weight per } \\
\text { item/g }\end{array}$ \\
\hline 1 & Bienne & Ipsach & $\begin{array}{r}47^{\circ} 07^{\prime} 19^{\prime \prime} \mathrm{N} \\
7^{\circ} 13^{\prime} 39^{\prime \prime} \mathrm{E}\end{array}$ & 136 & $\begin{array}{l}2 \text { March } \\
2019\end{array}$ & 54 & 0.40 & 6 & 0.67 \\
\hline 2 & & La Neuveville & $\begin{array}{r}47^{\circ} 03^{\prime} 36^{\prime \prime} \mathrm{N} \\
7^{\circ} 05^{\prime} 18^{\prime \prime} \mathrm{E}\end{array}$ & 25 & $\begin{array}{l}\text { 4 March } \\
2019\end{array}$ & 18 & 0.72 & 0 & 0.11 \\
\hline 3 & & Lüscherz & $\begin{array}{r}47^{\circ} 02^{\prime} 53^{\prime \prime} \mathrm{N} \\
7^{\circ} 09^{\prime} 05^{\prime \prime} \mathrm{E}\end{array}$ & 101 & $\begin{array}{l}2 \text { March } \\
2019\end{array}$ & 150 & 1.49 & 33 & 1.1 \\
\hline 4 & Brienz & Böningen, Lütschisand & $\begin{array}{r}46^{\circ} 41^{\prime} 26^{\prime \prime} \mathrm{N} \\
7^{\circ} 53^{\prime} 56^{\prime \prime} \mathrm{E}\end{array}$ & 130 & $\begin{array}{l}1 \text { March } \\
2019\end{array}$ & 44 & 0.34 & 7 & 0.86 \\
\hline 5 & & Brienz & $\begin{array}{r}46^{\circ} 44^{\prime} 39^{\prime \prime} \mathrm{N} \\
8^{\circ} 02^{\prime} 60^{\prime \prime} \mathrm{E}\end{array}$ & 90 & $\begin{array}{l}1 \text { March } \\
2019\end{array}$ & 443 & 4.92 & 66 & 3.0 \\
\hline 6 & & Iseltwald & $\begin{array}{r}46^{\circ} 42^{\prime} 41^{\prime \prime} \mathrm{N} \\
7^{\circ} 57^{\prime} 57^{\prime \prime} \mathrm{E}\end{array}$ & 25 & $\begin{array}{l}1 \text { March } \\
2019\end{array}$ & 20 & 0.80 & 5 & 3.9 \\
\hline 7 & Constance & $\begin{array}{l}\text { Arbon, Strandbad } \\
\text { Buchhorn }\end{array}$ & $\begin{array}{c}47^{\circ} 31^{\prime} 36^{\prime \prime} \mathrm{N} \\
9^{\circ} 25^{\prime} 8^{\prime \prime} \mathrm{E}\end{array}$ & 350 & $\begin{array}{l}15 \text { April } \\
2019\end{array}$ & 55 & 0.16 & 14 & 4.1 \\
\hline 8 & & Bodman G & $\begin{array}{r}47^{\circ} 47^{\prime} 20^{\prime \prime} \mathrm{N} \\
9^{\circ} 03^{\prime} 24^{\prime \prime} \mathrm{E}\end{array}$ & 1600 & $\begin{array}{l}16 \text { April } \\
2019\end{array}$ & 68 & 0.04 & 12 & 2.8 \\
\hline 9 & & Bregenz, Seecamping, A & $\begin{array}{r}47^{\circ} 30^{\prime} 25^{\prime \prime} \mathrm{N} \\
9^{\circ} 42^{\prime} 48^{\prime \prime} \mathrm{E}\end{array}$ & 90 & $\begin{array}{l}15 \text { April } \\
2019\end{array}$ & 372 & 4.13 & 40 & 1.5 \\
\hline 10 & & Kesswil, Badeplatz & $\begin{array}{r}47^{\circ} 36^{\prime} 02^{\prime \prime} \mathrm{N} \\
9^{\circ} 18^{\prime} 54^{\prime \prime} \mathrm{E}\end{array}$ & 250 & $\begin{array}{l}15 \text { April } \\
2019\end{array}$ & 29 & 0.12 & 9 & 3.0 \\
\hline 11 & & Kressbronn G & $\begin{array}{r}47^{\circ} 35^{\prime} 13^{\prime \prime} \mathrm{N} \\
9^{\circ} 35^{\prime} 15^{\prime \prime} \mathrm{E}\end{array}$ & 300 & $\begin{array}{l}16 \text { April } \\
2019\end{array}$ & 156 & 0.52 & 43 & 1.6 \\
\hline 12 & & Kreuzlingen, Seeburgpark & $\begin{array}{c}47^{\circ} 39^{\prime} 10^{\prime \prime} \mathrm{N} \\
9^{\circ} 11^{\prime} 8^{\prime \prime} \mathrm{E}\end{array}$ & 385 & $\begin{array}{l}15 \text { April } \\
2019\end{array}$ & 8 & 0.02 & 4 & 13.4 \\
\hline 13 & & $\begin{array}{l}\text { Langenargen, Uferpark } \\
\text { G }\end{array}$ & $\begin{array}{r}47^{\circ} 35^{\prime} 42^{\prime \prime} \mathrm{N} \\
9^{\circ} 32^{\prime} 34^{\prime \prime} \mathrm{E}\end{array}$ & 400 & $\begin{array}{l}16 \text { April } \\
2019\end{array}$ & 246 & 0.62 & 48 & 1.3 \\
\hline 14 & & $\begin{array}{l}\text { Lindau, Reutiner Bucht } \\
\text { G }\end{array}$ & $\begin{array}{l}47^{\circ} 33^{\prime} 2^{\prime \prime} \mathrm{N} \\
9^{\circ} 42^{\prime} 47^{\prime \prime} \mathrm{E}\end{array}$ & 30 & $\begin{array}{l}14 \text { April } \\
2019\end{array}$ & 396 & 13.2 & 52 & 1.4 \\
\hline 15 & & $\begin{array}{l}\text { Lindau, Eichwald Park } \\
\text { G }\end{array}$ & $\begin{array}{r}47^{\circ} 32^{\prime} 53^{\prime \prime} \mathrm{N} \\
9^{\circ} 42^{\prime} 58^{\prime \prime} \mathrm{E}\end{array}$ & 110 & $\begin{array}{l}14 \text { April } \\
2019\end{array}$ & 380 & 3.45 & 22 & 0.93 \\
\hline 16 & & Litzelstetten $\mathrm{G}$ & $\begin{array}{r}47^{\circ} 42^{\prime} 44^{\prime \prime} \mathrm{N} \\
9^{\circ} 10^{\prime} 51^{\prime \prime} \mathrm{E}\end{array}$ & 150 & $\begin{array}{l}15 \text { April } \\
2019\end{array}$ & 42 & 0.28 & 3 & 2.4 \\
\hline 17 & & Meersburg G & $\begin{array}{r}47^{\circ} 41^{\prime} 56^{\prime \prime} \mathrm{N} \\
9^{\circ} 15^{\prime} 27^{\prime \prime} \mathrm{E}\end{array}$ & 450 & $\begin{array}{l}16 \text { April } \\
209\end{array}$ & 71 & 0.16 & 19 & 1.1 \\
\hline 18 & & Münsterlingen & $\begin{array}{r}47^{\circ} 37^{\prime} 59^{\prime \prime} \mathrm{N} \\
9^{\circ} 14^{\prime} 29^{\prime \prime} \mathrm{E}\end{array}$ & 460 & $\begin{array}{l}15 \text { April } \\
2019\end{array}$ & 44 & 0.10 & 9 & 1.9 \\
\hline 19 & & Staad, Freibad Speck & $\begin{array}{r}47^{\circ} 28^{\prime} 58^{\prime \prime} \mathrm{N} \\
9^{\circ} 32^{\prime} 25^{\prime \prime} \mathrm{E}\end{array}$ & 75 & $\begin{array}{l}15 \text { April } \\
2019\end{array}$ & 367 & 4.89 & 68 & 2.2 \\
\hline 20 & Greifen & & $\begin{array}{r}47^{\circ} 22^{\prime} 00^{\prime \prime} \mathrm{N} \\
8^{\circ} 40^{\prime} 18^{\prime \prime} \mathrm{E}\end{array}$ & 50 & $\begin{array}{l}14 \text { April } \\
2019\end{array}$ & 8 & 0.16 & 1 & 2.6 \\
\hline 21 & Morat & Vallamand & $\begin{array}{r}46^{\circ} 55^{\prime} 46^{\prime \prime} \mathrm{N} \\
7^{\circ} 02^{\prime} 48^{\prime \prime} \mathrm{E}\end{array}$ & 16 & $\begin{array}{l}3 \text { March } \\
2019\end{array}$ & 36 & 2.25 & 7 & 3.2 \\
\hline 22 & Neuchâtel & Bevaix, Pointe du Grain & $\begin{array}{r}46^{\circ} 55^{\prime} 33^{\prime \prime} \mathrm{N} \\
6^{\circ} 50^{\prime} 14^{\prime \prime} \mathrm{E}\end{array}$ & 350 & $\begin{array}{l}3 \text { March } \\
2019\end{array}$ & 54 & 0.15 & 7 & 1.1 \\
\hline 23 & & Gletterens & $\begin{array}{r}46^{\circ} 54^{\prime} 30^{\prime \prime} \mathrm{N} \\
6^{\circ} 55^{\prime} 43^{\prime \prime} \mathrm{E}\end{array}$ & 107 & $\begin{array}{l}3 \text { March } \\
2019\end{array}$ & 17 & 0.16 & 4 & 0.24 \\
\hline 24 & & Ivonand & $\begin{array}{r}46^{\circ} 48^{\prime} 20^{\prime \prime} \mathrm{N} \\
6^{\circ} 44^{\prime} 13^{\prime \prime} \mathrm{E}\end{array}$ & 310 & $\begin{array}{l}3 \text { March } \\
2019\end{array}$ & 60 & 0.19 & 13 & 6.3 \\
\hline
\end{tabular}


Table 2 (continued)

\begin{tabular}{|c|c|c|c|c|c|c|c|c|c|}
\hline $\begin{array}{l}\text { Beach } \\
\text { ID }\end{array}$ & Lake & Beach $^{\mathrm{a}}$ & Location & $\begin{array}{l}\text { Beach } \\
\text { length/m }\end{array}$ & Date & $\begin{array}{l}\text { Number } \\
\text { of items }\end{array}$ & $\begin{array}{l}\text { Linear } \\
\text { density/ } \\
\text { item } \mathrm{m}^{-1}\end{array}$ & $\begin{array}{l}\text { Number of } \\
\text { analyses }\end{array}$ & $\begin{array}{l}\text { Mean } \\
\text { weight per } \\
\text { item/g }\end{array}$ \\
\hline 25 & & Vaumarcus A & $\begin{array}{r}46^{\circ} 52^{\prime} 38^{\prime \prime} \mathrm{N} \\
6^{\circ} 45^{\prime} 39^{\prime \prime} \mathrm{E}\end{array}$ & 20 & $\begin{array}{l}3 \text { March } \\
2019\end{array}$ & 10 & 0.50 & 4 & 4 \\
\hline 26 & & Vaumarcus B & $\begin{array}{r}46^{\circ} 52^{\prime} 43^{\prime \prime} \mathrm{N} \\
6^{\circ} 45^{\prime} 41^{\prime \prime} \mathrm{E}\end{array}$ & 64 & $\begin{array}{l}3 \text { March } \\
2019\end{array}$ & 19 & 0.30 & 6 & 3.4 \\
\hline 27 & Sempach & Nottwill & $\begin{array}{r}47^{\circ} 08^{\prime} 29^{\prime \prime} \mathrm{N} \\
8^{\circ} 08^{\prime} 11^{\prime \prime} \mathrm{E}\end{array}$ & 27 & $\begin{array}{l}\text { 4 March } \\
2019\end{array}$ & 48 & 1.78 & 3 & 0.31 \\
\hline 28 & & $\begin{array}{l}\text { Sempach, Restaurant } \\
\text { Seeland }\end{array}$ & $\begin{array}{r}47^{\circ} 07^{\prime} 33^{\prime \prime} \mathrm{N} \\
8^{\circ} 11^{\prime} 23^{\prime \prime} \mathrm{E}\end{array}$ & 40 & $\begin{array}{l}4 \text { March } \\
2019\end{array}$ & 44 & 1.10 & 10 & 1.25 \\
\hline 29 & Thun & Gwatt, Kander delta & $\begin{array}{r}46^{\circ} 43^{\prime} 12^{\prime \prime} \mathrm{N} \\
7^{\circ} 38^{\prime} 22^{\prime \prime} \mathrm{E}\end{array}$ & 40 & $\begin{array}{l}2 \text { March } \\
2019\end{array}$ & 41 & 1.03 & 4 & 0.49 \\
\hline 30 & & $\begin{array}{l}\text { Interlaken, Lombach } \\
\text { mouth }\end{array}$ & $\begin{array}{r}46^{\circ} 40^{\prime} 47^{\prime \prime} \mathrm{N} \\
7^{\circ} 48^{\prime} 47^{\prime \prime} \mathrm{E}\end{array}$ & 240 & $\begin{array}{l}1 \text { March } \\
2019\end{array}$ & 84 & 0.35 & 20 & 1.4 \\
\hline 31 & & Leissigen, church & $\begin{array}{r}46^{\circ} 39^{\prime} 19^{\prime \prime} \mathrm{N} \\
7^{\circ} 46^{\prime} 22^{\prime \prime} \mathrm{E}\end{array}$ & 22 & $\begin{array}{l}2 \text { March } \\
2019\end{array}$ & 14 & 0.64 & 4 & 12.7 \\
\hline 32 & & $\begin{array}{l}\text { Leissigen, Schreinerei } \\
\text { Heinrich }\end{array}$ & $\begin{array}{r}46^{\circ} 39^{\prime} 25^{\prime \prime} \mathrm{N} \\
7^{\circ} 46^{\prime} 37^{\prime \prime} \mathrm{E}\end{array}$ & 33 & $\begin{array}{l}2 \text { March } \\
2019\end{array}$ & 14 & 0.42 & 1 & 0.43 \\
\hline 33 & Zug & Hünenberg & $\begin{array}{r}47^{\circ} 10^{\prime} 13^{\prime \prime} \mathrm{N} \\
8^{\circ} 27^{\prime} 12^{\prime \prime} \mathrm{E}\end{array}$ & 30 & $\begin{array}{l}\text { 4 March } \\
2019\end{array}$ & 16 & 0.53 & 1 & 0.36 \\
\hline 34 & Zürich & $\mathrm{Au}$ & $\begin{array}{r}47^{\circ} 15^{\prime} 07^{\prime \prime} \mathrm{N} \\
8^{\circ} 38^{\prime} 37^{\prime \prime} \mathrm{E}\end{array}$ & 600 & $\begin{array}{l}19 \text { March } \\
2019\end{array}$ & 88 & 0.15 & 10 & 0.78 \\
\hline 35 & & Küsnacht & $\begin{array}{r}47^{\circ} 19^{\prime} 03^{\prime \prime} \mathrm{N} \\
8^{\circ} 34^{\prime} 36^{\prime \prime} \mathrm{E}\end{array}$ & 110 & $\begin{array}{l}18 \text { March } \\
2019\end{array}$ & 110 & 1.00 & 8 & 0.47 \\
\hline 36 & & $\begin{array}{l}\text { Meilen, Strandbad } \\
\text { Ländeli }\end{array}$ & $\begin{array}{r}47^{\circ} 15^{\prime} 48^{\prime \prime} \mathrm{N} \\
8^{\circ} 39^{\prime} 41^{\prime \prime} \mathrm{E}\end{array}$ & 26 & $\begin{array}{l}18 \text { March } \\
2019\end{array}$ & 62 & 2.38 & 13 & 2.1 \\
\hline 37 & & Schmerikon & $\begin{array}{r}47^{\circ} 13^{\prime} 29^{\prime \prime} \mathrm{N} \\
8^{\circ} 56^{\prime} 41^{\prime \prime} \mathrm{E}\end{array}$ & 33 & $\begin{array}{l}19 \text { March } \\
2019\end{array}$ & 80 & 2.42 & 11 & 0.78 \\
\hline 38 & & $\begin{array}{l}\text { Schmerikon, Aabach } \\
\text { delta }\end{array}$ & $\begin{array}{r}47^{\circ} 13^{\prime} 17^{\prime \prime} \mathrm{N} \\
8^{\circ} 56^{\prime} 25^{\prime \prime} \mathrm{E}\end{array}$ & 150 & $\begin{array}{l}19 \text { March } \\
2019\end{array}$ & 23 & 0.15 & 3 & 0.48 \\
\hline 39 & & Uerikon, Seebad Risi & $\begin{array}{r}47^{\circ} 14^{\prime} 05^{\prime \prime} \mathrm{N} \\
8^{\circ} 46^{\prime} 12^{\prime \prime} \mathrm{E}\end{array}$ & 30 & $\begin{array}{l}18 \text { March } \\
2019\end{array}$ & 89 & 2.97 & 8 & 0.66 \\
\hline
\end{tabular}

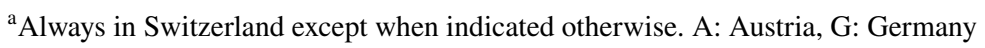

He GOLDD +) was employed to determine the elements that are deemed to be potentially hazardous according to various EU regulations (European Parliament \& Council of the EU, 2009; European Parliament and Council, 2011) and that are reported in our previous study of Lake Geneva (Filella \& Turner, 2018): As, $\mathrm{Ba}, \mathrm{Br}, \mathrm{Cd}, \mathrm{Cr}, \mathrm{Hg}, \mathrm{Pb}, \mathrm{Sb}$, and $\mathrm{Se}$, as well as $\mathrm{Cl}$ as a proxy for polyvinyl chloride ([Cl] $>150,000 \mathrm{ppm})$. The instrument was employed in the laboratory in a bench-top accessory stand with the surface of the sample to be probed (usually the thickest and flattest part) suspended centrally over the detector window and 8-mm diameter X-ray source on $3.6 \mu \mathrm{m}$ polyester film. Measurements were undertaken in a plastics mode coupled with a thickness correction algorithm down to $0.05 \mathrm{~mm}$ for a total period of $60 \mathrm{~s}(30 \mathrm{~s}$ each at $50 \mathrm{kV} / 40 \mu \mathrm{A}$ and $20 \mathrm{kV} / 100 \mu \mathrm{A}$ ), and spectra were quantified by fundamental parameters to yield elemental concentrations on a dry weight basis (in ppm) and with a counting error of $2 \sigma$ (95\% confidence). A few characteristic spectra are shown for illustration purposes at the end of Supporting Information file 2.

For quality assurance purposes, two Niton reference plastics, certified for either or both of As, $\mathrm{Ba}, \mathrm{Br}, \mathrm{Cd}, \mathrm{Cr}, \mathrm{Hg}, \mathrm{Pb}, \mathrm{Sb}$, and $\mathrm{Se}$ (PN 180-619, LOT\#T-18 and PN 180-554, batch SN PE-071-N), were analysed at regular intervals, returning 
concentrations that within $15 \%$ of certified values in each case. Under the operating conditions described above, detection limits were generally lowest and below $10 \mathrm{ppm}$ for $\mathrm{As}, \mathrm{Br}, \mathrm{Cr}$, and $\mathrm{Pb}$ and highest and above $70 \mathrm{ppm}$ for $\mathrm{Ba}, \mathrm{Sb}$, and $\mathrm{Sn}$. Note that in the case of As, overlap of its $\mathrm{K} \alpha$ fluorescence peak with the $\mathrm{L} \alpha$ peak of $\mathrm{Pb}$, coupled with the relatively low intensity of the As-K $\beta$ line, means that concentrations cannot be effectively calculated where $\mathrm{Pb}$ :As exceeds about 10 (Environmental Protection Agency, 2007). Arsenic concentrations reported in this study are, therefore, restricted to those returned by the XRF where $\mathrm{Pb}$ was not detected.

\section{Results and discussion}

Number and type of plastic samples

Overall, 3880 samples were collected, with a range of 8 to 443 on individual beaches, and the total mass of plastic was $6.825 \mathrm{~kg}$, with a mean item weight ranging from 0.11 to $13.4 \mathrm{~g}$ for individual beaches. Items could be classified as primary objects that were generally identifiable (e.g., bottle tops, straws, cotton buds, cartridges, clothes pegs, toys, pens, cigarette lighters, cable ties), secondary pieces whose source could be identified (e.g., remains of piping, insulating or adhesive tape, plant pots, sheeting, wrapping, bottles, footwear, rope, twine), secondary pieces that were fragmented beyond recognition, or fragments of expanded plastic that were typically fouled and discoloured (polystyrene, polyurethane).

The number of samples retrieved and the distribution of items in terms of classification and size varied considerably amongst the lakes studied. Although direct beach littering might account for a small number of items sampled (sampling was performed before the more general recreational use of the beaches), visual inspection of the samples (see photographs in Supporting Information files) and their preferential presence along the strandlines suggest that the majority of the beached plastic debris is derived from the water. This was also the case in our previous study of Lake Geneva but differs from observations in other lakes where sampling did not deliberately precede interventions like beach cleans (e.g., Hengstmann \& Fischer, 2020; Hoellein et al., 2015).
In oceans, plastics typically enter from land as mismanaged waste transported via rivers or wind (Kershaw \& Rochman, 2016; Rech et al., 2014; Schmidt et al., 2017), although local human deposition in coastal areas may also contribute (Hardesty et al., 2017). Given that land-based inputs are likely to be the most significant source of litter in the Swiss lakes rather than from beach visitors, variations in the amount and type of plastic accumulated on beaches might be expected to be attributable to factors such as proximity to inhabited areas and the size and nature of catchments and tributaries. Two cases, with relatively high quantities of plastic located close to river mouths, merit further discussion.

Beach \#5 in Lake Brienz ( $100 \mathrm{~m}$ in length), near to the mouth of the Aare River, returned 443 plastic items, many of which were relatively large and appeared to have been broken up recently. For comparison, the linear density of items was 4.92 items $\mathrm{m}^{-1}$ in beach \#5 and 0.34 and 0.80 items $\mathrm{m}^{-1}$ in beaches at Lütschisand (\#4), at the mouth of the Lütschine River, and Iseltwald (\#6), approximately equidistant from both river mouths, respectively. A detailed map is shown in pages 8 and 9 of the Supporting Information file 1 . Given the population upstream of both river mouths is similar and low (below 10,000), the high amount and characteristics of the plastics found in beach \#5 suggest a point contamination source. The fact that plastics do not disperse throughout the lake is explained by its morphology and the circulation of Aare River waters once in the lake (Chanudet \& Filella, 2008; Wuest et al., 2007).

A completely different situation exists in Lake Constance, where the eastern reaches accumulate all kinds of natural and anthropogenic debris because of the dominant westerly winds and the proximity to the inflow from the Rivers Rhine and Bregenzer Aach (Mürle et al., 2004). The Rhine mouth was diverted several times before 2000 by building an artificial channel into the lake which directs the riverine sediment load to the lake deep basin in order to prevent the silting up of Bregenzer and Fussacher bays (Mürle et al., 2004). However, the light fraction of the river suspended matter, including wood and plastics, is still carried eastwards by winds and surface currents. This is reflected by the highest quantities of plastic samples ( 400) retrieved from the most easterly or southeasterly beaches at Lindau (\#14 and \#15), Bregenz (\#9), and Staad (\#19). The difference of the linear density of 
Table 3 A summary of detection frequencies and concentrations for the hazardous elements measured in plastics from the Swiss lakes given in Table 2. The total number of samples analysed was 598, and data from Lake Geneva are shown for comparison

\begin{tabular}{|c|c|c|c|c|c|c|c|}
\hline Element & $\begin{array}{l}\text { Number }(\%) \text { of } \\
\text { positives }\end{array}$ & Median/ppm & Minimum/ppm & Maximum/ppm & $1 \mathrm{Q} / \mathrm{ppm}$ & $3 \mathrm{Q} / \mathrm{ppm}$ & $\begin{array}{l}\text { Lake Geneva } \\
\text { median/ppm }\end{array}$ \\
\hline $\mathrm{Sb}$ & $39(6.5)$ & 118 & 30.6 & 88,400 & 59.0 & 171 & 183 \\
\hline$A s^{b}$ & $10(1.7)$ & 9.9 & 3.7 & 48.3 & 7.3 & 14.1 & 6.3 \\
\hline $\mathrm{Ba}$ & $340(48.7)$ & 598 & 157 & 144,000 & 391 & 1320 & 670 \\
\hline $\mathrm{Br}$ & 105 (17.6) & 32.4 & 3.4 & 7990 & 17.1 & 74.4 & 64.6 \\
\hline $\mathrm{Cd}$ & 68 (11.4) & 493 & 17.8 & 20,000 & 97.3 & 871 & 1120 \\
\hline $\mathrm{Cr}$ & $216(36.1)$ & 118 & 17.1 & 20,900 & 46.9 & 687 & 48.8 \\
\hline $\mathrm{Pb}$ & $201(33.6)$ & 192 & 6.3 & 35,700 & 48.3 & 2960 & 585 \\
\hline $\mathrm{Hg}^{\mathrm{c}}$ & $2(0.3)$ & $33.5,73.7$ & & & & & 68.6 \\
\hline $\mathrm{Se}$ & $16(2.7)$ & 460 & 141 & 2020 & 270 & 797 & 394 \\
\hline
\end{tabular}

${ }^{a}$ Median concentration values as reported in Filella and Turner (2018) for 670 samples analysed. Note that the Ba value, not previously published, has been calculated here from the original data $(n=243)$

${ }^{b}$ Excludes values arising from the spectral interference by lead

${ }^{\mathrm{c}}$ The two individual concentrations measured are given rather than the median value

items (number of items normalised by beach length) between these four beaches and the rest of beaches in Lake Constance is statistically significant $(p=0.007$, Mann-Whitney pairwise test). Thereafter, there is a broad reduction in plastic abundance with increasing distance from this region. A detailed map is found in pages 19 and 20 of the Supporting Information file 1.

Because land-based (riverine) sources are prevalent and common to all lakes studied, many of the types of items retrieved from each lake, and described above, are generic. Some objects, however, were present only in a given lake, indicating specific local origins of certain types of plastic waste. For instance, small green or blue pellets used in wastewater treatment plants were mostly found in beaches of Lake Zurich and many black plastic firework casings and other remains of fireworks were extremely abundant on some of the beaches of Lake Constance.

Occurrence and concentrations of hazardous elements

Table 3 summarizes the detection frequencies and concentrations of hazardous elements in the beached lake plastics analyzed by XRF spectrometry $(n=598)$. Note that data have been combined for all lakes. Also given in Table 3 for comparison are corresponding data for Lake Geneva, Switzerland's largest lake by surface area and volume, and as published in Filella and Turner (2018).

In our survey, only two objects (both retrieved from beach \#11, Lake Constance, and indicated in the Supporting Information file 1, page 30) contained detectable $\mathrm{Hg}$. Namely, the remains of a black shoe sole $(73.7 \mathrm{ppm})$ that also contained detectable $\mathrm{Pb}$ (290 ppm), Br (63 ppm), and Cr (630 ppm), and a small red fragment $(33.5 \mathrm{ppm})$ that also contained detectable $\mathrm{Pb}(95.5 \mathrm{ppm})$. The presence of $\mathrm{Hg}$ in the shoe sole may be attributed to a catalytic residue of polyurethane production, but the origin of the $\mathrm{Hg}$ in the red fragment is unknown because the absence of $\mathrm{Cd}$ rules out a $\mathrm{Cd}-\mathrm{Hg}$ sulphide-based pigment that was found in several Lake Geneva plastics.

Cadmium has been used as a stabiliser in PVC and as a series of brightly coloured pigments in a variety of plastics. PVC producers and stake-holders voluntarily committed to the phasing out of Cd- (and $\mathrm{Pb}-)$ based stabilizers in the EU and, more generally, various regulations limit the amount or deliberate addition of $\mathrm{Cd}$ into consumer plastics (Turner, 2019). Despite these restrictions, Cd was detected in 68 samples analysed encompassing all lakes studied, of which 15 were composed of PVC. This may be attributed to the fact that rigid PVC and plastics pigmented with $\mathrm{Cd}$ have often been used in products with relatively long lifetimes (e.g., pipes and fittings, 


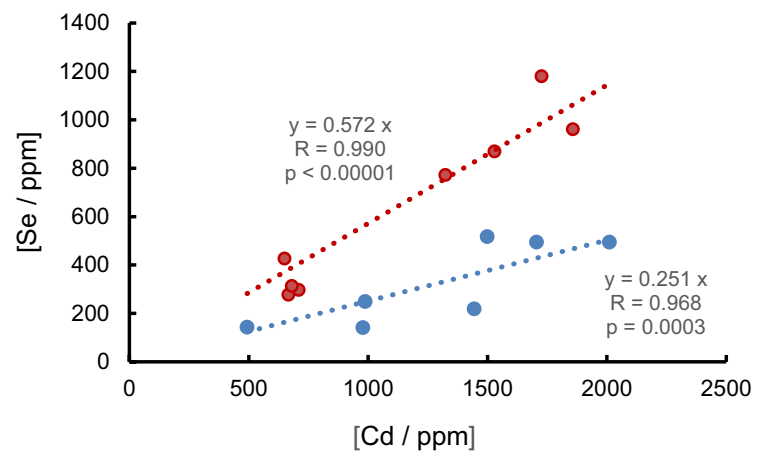

Fig. 2 Concentrations of Se versus concentrations of $\mathrm{Cd}$ in lake plastic samples. Annotated are equations of best fit for the data split into two groups and defined by red circles (all red in colour) and blue circles (mostly red but also include an orange piece, a blue PVC cable, and a black non-PVC tube). They are given for illustrative purposes

hoses, gutters, door and window frames, profiles and plates, roof plates, toys) that continue to contaminate the contemporary waste stream, and the metal readily contaminates plastic recycled from electronic waste (Tamaddon \& Hogland, 1993).

Selenium was detected in 16 samples, two of which were PVC and all of which contained detectable $\mathrm{Cd}$. Selenium is combined with $\mathrm{Cd}$ in sulphoselenide pigments whose precise colour (from yellow through to red) can be adjusted by increasing the ratio of Se to $\mathrm{S}$ in the solid solution. The Se:Cd ratios in our samples, plotted in Fig. 2, point to the use of at least two different sulphoselenides with mean ratios of about 0.57 and 0.25 . The latter ratio is similar to that determined for Se:Cd in plastics sampled from beaches of Lake Geneva (about 0.22; Filella \& Turner, 2018).

Like $\mathrm{Cd}, \mathrm{Pb}$ has been used as a stabiliser in PVC and as a pigment in a variety of plastics and has been subject to similar regulations and voluntary phase-out (Turner \& Filella, 2021a, 2021b, 2021c). Lead was detected in a third of the samples analysed (201) across all lakes, including 18 constructed of PVC, with concentrations ranging from about 6 to $35,000 \mathrm{ppm}$. All but four PVC objects contained $\mathrm{Pb}$ concentrations above $1000 \mathrm{ppm}$. The principal pigments of $\mathrm{Pb}$ used in a variety of plastics are based on lead chromate, $\mathrm{PbCrO}_{4}$, and the data plotted in Fig. 3 reveal that some of the samples can be defined by a mass ratio of $\mathrm{Pb}: \mathrm{Cr}$ of about 4 , close to the theoretical mass ratio of the metals in lead chromate. Data defined by a line of a smaller slope suggest the use

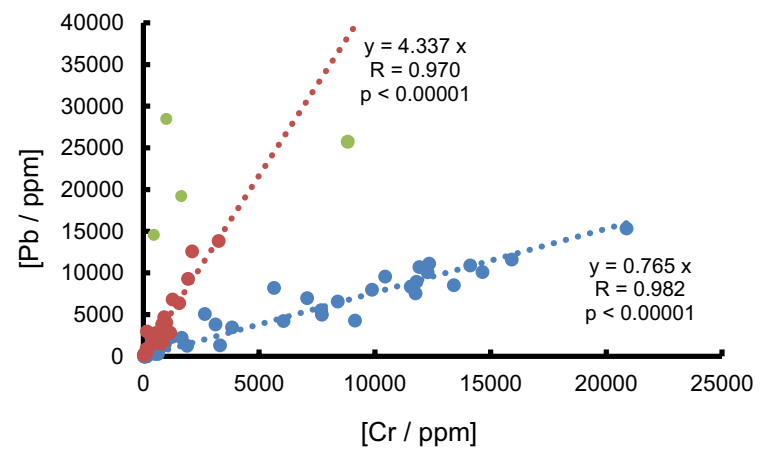

Fig. 3 Concentrations of $\mathrm{Pb}$ versus concentrations of $\mathrm{Cr}$ in lake plastic samples. Data in red and blue are defined by the best-fit lines annotated, while data in green do not conform to either relationship. They are given for illustrative purposes

of $\mathrm{Cr}$ in additional pigments and additives or its presence as catalytic residue (e.g., chromium oxide). Some black plastic firework casings, extremely abundant in some beaches of Lake Constance, also contained $\mathrm{Pb}$.

Where any potential spectral interferences from $\mathrm{Pb}$ could be ruled out, ten samples from seven different beaches (in Lakes Zurich (2), Neuchâtel (2), and Constance (3)) contained detectable As with concentrations in the 3.7 to $16.3 \mathrm{ppm}$ range. Arsenic compounds are known to have been used as antimicrobials in various plastics (Stenmarck et al., 2017) but no particular characteristics of the present objects (e.g., colour, type, usage) enable the origin of As to be ascertained.

Bromine was detected in 105 samples across all lakes, with concentrations ranging from 3.4 to $144,000 \mathrm{ppm}$. Bromine may be present in some cases as a component of the blue-green pigment, copper phthalocyanine (Lewis, 2004), but is more generally present in plastics because of the addition of brominated flame retardants to electronic plastics and furnishings or to their contamination of plastics more generally through recycling of waste electronic material (Guzzonato et al., 2017). Brominated flame retardants encompass a variety of compounds, some of which, including polybrominated biphenyls (PBB) and polybrominated diphenyl ethers (PBDE), are now restricted. Although XRF spectrometry is unable to discriminate different compounds of the same element, the co-association of $\mathrm{Br}$ with $\mathrm{Sb}$, a component of the flame retardant synergist, $\mathrm{Sb}_{2} \mathrm{O}_{3}$, may afford an indirect means of establishing the broad nature of the brominated flame retardant(s) present (Puype et al., 
2015). Antimony was detected in 39 samples across the lakes but was only co-associated with $\mathrm{Br}$ in six cases and, unlike samples from Lake Geneva, exhibited no distinct relationship with the halogen. The highest $\mathrm{Sb}$ concentration $(88,400 \mathrm{ppm})$ occurred in a Br-free sample of grey PVC ribbon from Lüscherz (Lake Bienne) where it was present, presumably, as a flame retardant synergist for the chlorinated polymer. Antimony was more widely detectable at relatively low concentrations $(<500 \mathrm{ppm})$ and in the absence of $\mathrm{Br}$ which might be attributed to residual, catalytic $\mathrm{Sb}_{2} \mathrm{O}_{3}$ used in the production of polyethylene terephthalate (Filella, 2020).

Amongst the elements analysed, $\mathrm{Ba}$ was detected in the most cases (340) and across all lakes, with concentrations ranging from 157 to $144,000 \mathrm{ppm}$. The most commonly employed $\mathrm{Ba}$ compound in plastic is $\mathrm{BaSO}_{4}$ which acts as an inert, white filler and extender, especially where an increase in specific gravity is required (Gooch, 2011).

\section{Discussion}

Is the presence of beached plastics in Swiss lakes a surprise?

Obviously, not. Plastics have been reported on lake beaches (Driedger et al., 2015; Mayoma et al., 2019; Vincent \& Hoellein, 2017) as a result of usage and subsequent mismanagement and include single-use and multi-use consumer articles and recognisable and unidentifiable pieces, fragments, and films. Indeed, according to Geyer et al. (2017), 8300 million metric tonnes of polymer resins, synthetic fibres, and additives had been globally produced up to 2015, of which $79 \%$ had accumulated in landfills or had been mismanaged and ended up in the environment. In the case of Switzerland, a probabilistic material flow analysis applied to seven polymers estimated a combined emission to surface waters in Switzerland of $109 \pm 40 \mathrm{t}$ of macroplastics and $15 \pm 9 \mathrm{t}$ of microplastics in 2014 (Kawecki \& Nowack, 2019). Thus, the presence of a range of plastics on Swiss lake beaches is not unexpected.

Can we establish the origins of beached plastics?

A detailed analysis and rigorous source appointment of plastic debris in all lakes studied require extensive temporal and spatial sampling campaigns, such as the national one currently in place for litter in Swiss freshwater systems (https://hammerdirt-analyst. github.io/IQAASL-End-0f-Sampling-2021/end_ of_sampling_iqaasl/eos_asa.html/). For instance, this campaign has performed 386 surveys from 143 locations from April 2020 to May 2021 by using a modified OSPAR/Marine litter watch protocol and 54'744 objects have been collected. The influence of indicators such as population, surface area uses (e.g., buildings, woods, outdoor activities, agriculture, length of all roads and trails), number of river discharge intersections, etc. has been evaluated. Establishing such, or other, correlations with our data was not the objective of this study and, obviously, would have no statistical meaning with our limited number of samples and sample campaigns. It is clear, however, that the two cases discussed above (Lake Brienz and Lake Constance) confirm that rivers play a key role in 'feeding' lakes with plastics.

What measuring some chemical element contents in plastics tell us

First, the presence of potentially hazardous elements in the mismanaged plastics is always of concern even if it is unclear whether they imply any serious ecotoxicological impact. A few studies that have been performed using unrealistically high concentrations of microplastics - $\mathrm{a}$ common trait in (eco)toxicity studies involving such particulates (Lenz et al., 2016; Phuong et al., 2016)—suggest toxic effects arising from metals as additives or having been acquired (adsorbed) from the environment ( $\mathrm{Lu}$ et al., 2016; Boyle et al., 2020) but, in practice, it remains an unexplored question. Secondly, in some cases, the presence of certain chemical elements can also point to local and contemporary noxious sources. This is the case, for instance, of Pb-rich black plastic firework casings abundant in some beaches of Lake Constance.

However, the determination of the concentration of some targeted elements in beached plastics as a tool to understand the cycling of plastic litter has a utility well beyond possible ecotoxicological considerations or spotting problematic local sources. Plastics have been accumulating for several decades either in the lakes or in the standing stock and knowing the lifespan of plastic debris and their environmental fate are 
needed to introduce adequate management schemes. Plastic debris age might be deduced visually from their condition, but this approach provides very limited qualitative information. The degradation of plastics in the environment can be followed by using spectroscopic or microscopic techniques (Brandon et al., 2016; Ioakeimidis et al., 2016), but they only provide information about polymer degradation. This can be due to many factors, and degradation is not easy to link to the persistence of the plastic in the system. It is here where detecting the presence of some chemical elements in the plastics (e.g., As, $\mathrm{Cd}, \mathrm{Hg}, \mathrm{Pb}$ ) provide a useful, alternative tool. In our initial study in Lake Geneva (Filella \& Turner, 2018), we detected the presence of restricted additives, some of which, such as $\mathrm{Hg}$, had been phased out many decades ago. Potentially hazardous chemical elements found in this study seem to be largely absent in common plastic consumer products in Switzerland (which is expected in accordance with current regulations), except in a very few recycled objects $(\mathrm{Cd}$ and $\mathrm{Pb}$, with $\mathrm{As}$ and $\mathrm{Hg}$ entirely absent) (Filella, 2020). This points to long residence times of these items in lakes that considerably exceed hydraulic residence times.

A second group of chemical elements that might provide useful information is those present in additives that have an impact on the physical properties of plastics, and in particular on density. This effect has been exploited in the recycling industry in order to separate harmful and recyclable plastics (for example, Br-free and Br-positive materials; Retegan et al., 2010) and was recently addressed in terms of natural plastic fractionation in the marine environment (Turner \& Filella, 2020; 2021a). Significantly, many polymers, including the polyolefins, have a density that is marginally below that of temperate freshwater $\left(1.0 \mathrm{~g} \mathrm{~mL}^{-1}\right)$ and the presence of moderate quantities of relatively dense additives, like $\mathrm{BaSO}_{4}\left(4.5 \mathrm{~g} \mathrm{~mL}^{-1}\right)$ or $\mathrm{PbCrO}_{4}\left(6.3 \mathrm{~g} \mathrm{~mL}^{-1}\right)$, may incur a positive settling velocity to the material and increase its retention time in lakes. Our median value for Ba (598 ppm) (and the corresponding value in Lake Leman, $670 \mathrm{ppm}$ ) is significantly different from the median value of $1540 \mathrm{ppm}$ for consumer products reported in Turner and Filella (2020). Although this could suggest a fractionation of plastics, with 'heavier' ones remaining in lakes, this observation needs to be considered with caution because the choice of objects to analyse in this study was focused on objects prone to contain potentially hazardous elements. Since $\mathrm{Ba}$ is present in many 'innocuous' plastics, a sound conclusion would require the analysis of all objects collected.

In conclusion, the observations of the present study, coupled with their similarities with findings previously reported in Lake Geneva (median elemental concentrations not statistically different, $p=0.25$, Wilcoxon two-sample paired test) and the lack of hazardous elements in current consumer plastics, illustrate how the measurement of these chemicals in lake beached plastics provides a powerful tool to understand plastic cycling in catchments of varying hydrodynamic and geomorphological characteristics. After this proof-of-concept exercise, a next step would be the coupling of this approach with a wider sampling exercise in order to evaluate the relative significance of different sources.

Funding Open Access funding provided by Université de Genève.

Data availability Data will be made available on reasonable request.

Open Access This article is licensed under a Creative Commons Attribution 4.0 International License, which permits use, sharing, adaptation, distribution and reproduction in any medium or format, as long as you give appropriate credit to the original author(s) and the source, provide a link to the Creative Commons licence, and indicate if changes were made. The images or other third party material in this article are included in the article's Creative Commons licence, unless indicated otherwise in a credit line to the material. If material is not included in the article's Creative Commons licence and your intended use is not permitted by statutory regulation or exceeds the permitted use, you will need to obtain permission directly from the copyright holder. To view a copy of this licence, visit http://creativecommons.org/licenses/by/4.0/.

\section{References}

Barnes, D. K. A., Galgani, F., Thompson, R. C., \& Barlaz, M. (2009). Accumulation and fragmentation of plastic debris in global environments. Philosophical Transactions of the Royal Society B: Biological Sciences, 364, 1985-1998. https://doi.org/10.1098/rstb.2008.0205

Beaumont, N. J., Aanesen, M., Austen, M. C., Borger, T., Clark, J. R., Cole, M., Hooper, T., Lindeque, P. K., Pascoe, C., \& Wyles, K. J. (2019). Global ecological, social and economic impacts of marine plastic. Marine Pollution Bulletin, 142, 189-195. https://doi.org/10.1016/j.marpolbul. 2019.03.022

Blettler, M. C. M., Abrial, E., Khan, F. R., Sivri, N., \& Espinola, L. A. (2018). Freshwater plastic pollution: Recognizing research 
biases and identifying knowledge gaps. Water Research, 143, 416-424. https://doi.org/10.1016/j.watres.2018.06.015

Boyle, D., Catarino, A. I., Clark, N. J., \& Henry, T. B. (2020). Polyvinyl chloride (PVC) plastic fragments release $\mathrm{Pb}$ additives that are bioavailable in zebrafish. Environmental Pollution, 263, 114422. https://doi.org/10.1016/j.envpol. 2020.114422

Brandon, J., Goldstein, M., \& Ohman, M. D. (2016). Long-term aging and degradation of microplastic particles: Comparing in situ oceanic and experimental weathering patterns. Marine Pollution Bulletin, 110, 299-308. https://doi.org/10. 1016/j.marpolbul.2016.06.048

Carpenter, E. J., \& Smith, K. L., Jr. (1972). Plastics on the Sargasso Sea surface. Science, 175, 1240-1241. https://doi. org/10.1126/science.175.4027.1240

Chanudet, V., \& Filella, M. (2008). Size and composition of inorganic colloids in a peri-alpine, glacial flour-rich lake. Geochimica et Cosmochimica Acta, 72, 1466-1479. https://doi.org/10.1016/j.gca.2008.01.002

Collard, F., Gasperi, J., Gilbert, B., Eppe, G., Azimi, S., Rocher, V., \& Tassin, B. (2018). Anthropogenic particles in the stomach contents and liver of the freshwater fish Squalius cephalus. Science of the Total Environment, 643, 12571264. https://doi.org/10.1016/j.scitotenv.2018.06.313

Colton, J. B., Jr., Knapp, F. D., \& Burns, B. R. (1974). Plastic particles in surface waters of the Northwestern Atlantic. Science, 185, 491-497. https://doi.org/10.1126/science. 185.4150.491

Driedger, A. G. J., Durr, H. H., Mitchell, K. K., \& Van Cappellen, P. (2015). Plastic debris in the Laurentian Great Lakes: A review. Journal of Great Lakes Research, 41, 9-19. https:// doi.org/10.1016/j.jglr.2014.12.020

Environmental Protection Agency. (2007). Method 6200 Field portable X-ray fluorescence spectrometry for the determination of elemental concentrations in soil and sediment. http://www3.epa.gov/epawaste/hazard/testmethods/ sw846/pdfs/6200.pdf.\%20Accessed\%207/16 http://www3. epa.gov/epawaste/hazard/testmethods/sw846/pdfs/6200. pdf. Accessed 7/16

European Parliament and Council of the EU. (2009). Directive 2009/48/EC of the European Parliament and of the Council of 18 June 2009 on the safety of toys. Official Journal of the European Union, L170/1

European Parliament and Council. (2011). Directive 2011/65/ EU on the restriction of the use of certain hazardous substances in electrical and electronic equipment (recast). Official Journal of the European Union, L174/88

Filella, M. (2019). Trace element analysis of 50 plastic consumer products. https://doi.org/10.13097/archive-ouverte/ unige: 149776

Filella, M. (2020). Antimony and PET bottles: Checking facts. Chemosphere, 261, 127732. https://doi.org/10.1016/j. chemosphere.2020.127732

Filella, M., \& Turner, A. (2018). Observational study unveils the extensive presence of hazardous elements in beached plastics from Lake Geneva. Frontiers in Environmental Science, 6, 1. https://doi.org/10.3389/fenvs.2018.00001

France, R. (1992). Garbage in paradise. Nature, 365, 504

Geyer, R., Jambeck, J. R., \& Lavender Law, K. (2017). Production, use, and fate of all plastics ever made. Science Advances, 3, e1700782. https://doi.org/10.1126/sciadv.1700782
Gooch, J.W. (2011). Encyclopedic dictionary of polymers. 2nd Edition, Springer, 1015pp.

Guzzonato, A., Puype, F., \& Harrad, S. J. (2017). Evidence of bad recycling practices: BFRs in children's toys and food-contact articles. Environmental Science: Processes \& Impacts, 19, 956-963. https://doi.org/10.1039/C7EM0 0160F

Hahladakis, J. N., Velis, C. A., Weber, R., Iacovidou, E., \& Purnell, P. (2018). An overview of chemical additives present in plastics: Migration, release, fate and environmental impact during their use, disposal and recycling. Journal of Hazardous Materials, 344, 179-199. https://doi.org/10. 1016/j.jhazmat.2017.10.014

Hardesty, B. D., Harari, J., Isobe, A., Lebreton, L., Maximenko, N., Potemra, J., et al. (2017). Using numerical model simulations to improve the understanding of microplastic distribution and pathways in the marine environment. Frontiers in Marine Science, 4, 30. https://doi.org/ 10.3389/fmars.2017.00030

Hengstmann, E., \& Fischer, E. K. (2020). Anthropogenic litter in freshwater environments-Study on lake beaches evaluating marine guidelines and aerial imaging. Environmental Research, 189, 109945. https://doi.org/10.1016/j. envres.2020.109945

Hoellein, T. J., Westhoven, M., Lyandres, O., \& Cross, J. (2015). Abundance and environmental drivers of anthropogenic litter on Lake Michigan beaches: A study facilitated by citizen science data collection. Journal of Great Lakes Research, 41, 78-86. https://doi.org/10.1016/j.jglr. 2014.12.015

Ioakeimidis, C., Fotopoulou, K. N., Karapanagioti, H. K., Geraga, M., Zeri, C., Papathanassiou, E., Galgani, F., \& Papatheodorou, G. (2016). The degradation potential of PET bottles in the marine environment: An ATR-FTIR based approach. Science and Reports, 6, 23501. https://doi.org/ 10.1038/srep23501

Karlsson, T. M., Hassellov, M., \& Jakubowicz, I. (2018). Influence of thermooxidative degradation on the in situ fate of polyethylene in temperate coastal waters. Marine Pollution Bulletin, 135, 187-194. https://doi.org/10. 1016/j.marpolbul.2018.07.015

Kawecki, D., \& Nowack, B. (2019). Polymer-specific modeling of the environmental emissions of seven commodity plastics as macro- and microplastics. Environmental Science and Technology, 53, 9664-9676. https://doi.org/10.1021/ acs.est.9b02900

Kershaw, P. J., Rochman, C. M. (eds.) (2016). Sources, fate and effects of microplastics in the marine environment: Part 2 of a global assessment. IMO/FAO/UNESCO- IOC/ UNIDO/WMO/IAEA/UN/UNEP/UNDP Joint Group of Experts on the Scientific Aspects of Marine Environmental Protection, Rep. Stud. GESAMP No. 93, 220 p. Available at: www.gesamp.org/publications/microplastics-inthe-marine-environment-part-2. Accessed January 2021

Krelling, A. P., Williams, A. T., \& Turra, A. (2017). Differences in perception and reaction of tourist groups to beach marine debris that can influence a loss of tourism revenue in coastal areas. Marine Policy, 85, 87-99. https://doi.org/ 10.1016/j.marpol.2017.08.021

Lambert, S., \& Wagner, M. (2016). Formation of microscopic particles during the degradation of different polymers. 
Chemosphere, 161, 510-517. https://doi.org/10.1016/j. chemosphere.2016.07.042

Lenz, R., Enders, K., \& Nielsen, T. G. (2016). Microplastic exposure studies should be environmentally realistic. Proceedings of the National Academy of Sciences of the United States of America, 113, E4121-E4122. https://doi. org/10.1073/pnas.1606615113

Lewis, P. A. (2004). Organic colorants, in: Coloring of plastics: Fundamentals, 2nd Edition, ed. R.A. Charvat (Hoboken, NJ: John Wiley), pp100-126.

Lu, Y., Zhang, Y., Deng, Y., Jiang, W., Zhao, Y., Geng, J., et al. (2016). Uptake and accumulation of polystyrene microplastics in zebrafish (Danio rerio) and toxic effects in liver. Environmental Science and Technology, 50, 4054-4060. https:// doi.org/10.1021/acs.est.6b00183

Mayoma, B. S., Mjumira, I. S., Efudala, A., Syberg, K., \& Khan, F. R. (2019). Collection of anthropogenic litter from the shores of Lake Malawi: Characterization of plastic debris and the implications of public involvement in the African Great Lakes. Toxics, 7, 64. https://doi.org/10. 3390/toxics7040064

Mürle, U., Ortlepp, J., Rey, P. (2004). Der Bodensee. Zustand Fakten - Perspektiven. Bilanz 2004, Internationale Gewasserschutzkommission für den Bodensee (IGKB). Bregenz, Austria, 177 pp. Available at: https://docplayer.org/111339751Igkbinternationale-der-bodensee-zustand-fakten-perspektivengewaessers chutzkommission-fuer-den-boden see.html. Accessed: January 2021

Oehlmann, J., Schulte-Oehlmann, U., Kloas, W., Jagnytsch, O., Lutz, I., Kusk, K. O., Wollenberger, L., Santos, E. M., Paull, G. C., Van Look, K. J. W., \& Tyler, C. R. (2009). A critical analysis of the biological impacts of plasticizers on wildlife. Philosophical Transactions of the Royal Society of London. Series B, 364, 2047-2062. https://doi.org/ 10.1098/rstb.2008.0242

OSPAR Commission. (2010). Guideline for Monitoring Marine Litter on the Beaches in the OSPAR Maritime Area. Available at: www.ospar.org/ospar-data/10-02e_ beachlitterguideline_englishonly.pdf

Phuong, N. N., Zalouk-Vergnoux, A., Poirier, L., Kamari, A., Chatel, A., Mouneyrac, C., \& Lagarde, F. (2016). Is there any consistency between the microplastics found in the field and those used in laboratory experiments? Environmental Pollution, 211, 111-123. https://doi.org/10.1016/j. envpol.2015.12.035

Puype, F., Samsonek, J., Knoop, J., Egelkraut-Holtus, M., \& Ortlieb, M. (2015). Evidence of waste electrical and electronic equipment (WEEE) relevant substances in polymeric food-contact articles sold on the European market. Food Additives \& Contaminants A, 32, 410-426

Rech, S., Macaya-Caquilpan, V., Pantoja, J. F., Rivadeneira, M. M., Jofre Madariaga, D., \& Thiel, M. (2014). Rivers as a source of marine litter-A study from the SE Pacific. Marine Pollution Bulletin, 82, 66-75. https://doi.org/10. 1016/j.marpolbul.2014.03.019

Retegan T, Felix J, Schyllander J. (2010). Recycling of WEEE plastics containing brominated flame retardants-Aa Swedish perspective report to the Swedish Environmental Protection Agency. Available at: www.ivl.se. Accessed January 2021

Ryan, P. G., Lamprecht, A., Swanepoel, D., \& Moloney, C. L. (2014). The effect of fine-scale sampling frequency on estimates of beach litter accumulation. Marine Pollution Bulletin, 88, 249-254. https://doi.org/10.1016/j.marpolbul. 2014.08.036

Scherer, C., Brennholt, N., Reifferscheid, G., \& Wagner, M. (2017). Feeding type and development drive the ingestion of microplastics by freshwater invertebrates. Science and Reports, 7, 17006. https://doi.org/10.1038/ s41598-017-17191-7

Schmidt, C., Krauth, T., \& Wagner, S. (2017). Export of plastic debris by rivers into the sea. Environmental Science and Technology, 51, 12246-12253. https://doi.org/10.1021/ acs.est. $7 \mathrm{~b} 02368$

Stenmarck, A., Belleza, E. L., Fråne, A., Busch, N., Larsen, Å., M. Wahlström, M. (2017). Hazardous substances in plastics-Ways to increase recycling. TemaNord 505. Nordic Council of Ministers, Copenhagen. Available at: www.norden.org. Accessed: January 2021

Tamaddon, F., \& Hogland, W. (1993). Review of cadmium in plastic waste in Sweden. Waste Management \& Research, 11, 287-295. https://doi.org/10.1177/0734242X9301100403

Turner, A. (2019). Cadmium pigments in consumer products and their health risks. Science of the Total Environment, 657, 1409-1418. https://doi.org/10.1016/j.scitotenv.2018. 12.096

Turner, A., \& Filella, M. (2020). The influence of additives on the fate of plastics in the marine environment, exemplified with barium sulphate. Marine Pollution Bulletin, 158, 111352. https://doi.org/10.1016/j.marpolbul.2020.111352

Turner, A., \& Filella, M. (2021a). Corrigendum to "The influence of additives on the fate of plastics in the marine environment, exemplified with barium sulphate" [Mar. Pollut. Bull. 158 (2020a) 111352]. Marine Pollution Bulletin, 162, 111787. https://doi.org/10.1016/j.marpolbul.2020. 111787

Turner, A., \& Filella, M. (2021b). Lead in plastics-Recycling of legacy material and appropriateness of current regulations. Journal of Hazardous Materials, 404, 124131. https://doi.org/10.1016/j.jhazmat.2020.124131

Turner, A., \& Filella, M. (2021c). Hazardous metal additives in plastics: Historical use, dispersion through recycling, current European regulations and environmental impacts. Environment International, 156, 106622. https://doi.org/ 10.1016/j.envint.2021.106622

Turner, A., \& Solman, K. R. (2016). Analysis of the elemental composition of marine litter by field-portable-XRF. Talanta, 159, 262-271. https://doi.org/10.1016/j.talanta. 2016.06.026

Vincent, A. E. S., \& Hoellein, T. J. (2017). Anthropogenic litter abundance and accumulation rates point to seasonal litter sources on a Great Lakes beach. Journal of Contemporary Water Research \&Education, 160, 72-84. https://doi. org/10.1111/j.1936-704X.2017.03241.x

Wuest, A., Zeh, M., \& Ackermann, J. D. (2007). Preface: Lake Brienz Project: An interdisciplinary catchment-to-lake study. Aquatic Sciences, 69, 173-178. https://doi.org/10. 1007/s00027-007-0016-0

Publisher's Note Springer Nature remains neutral with regard to jurisdictional claims in published maps and institutional affiliations. 